\title{
MMRR \\ 2014: Volume 4, Number 1
}

A publication of the Centers for Medicare \& Medicaid Services, Office of Information Products \& Data Analytics

\section{Impacts of Generic Competition and Benefit Management Practices on Spending for Prescription Drugs: Evidence from Medicare's Part D Benefit}

\author{
Steven Sheingold \& Nguyen Xuan Nguyen \\ U.S. Department of Health and Human Services-Office of the Assistant Secretary for \\ Planning and Evaluation
}

Objective: This study estimates the effects of generic competition, increased cost-sharing, and benefit practices on utilization and spending for prescription drugs.

Data and Methods: We examined changes in Medicare price and utilization from 2007 to 2009 of all drugs in 28 therapeutic classes. The classes accounted for $80 \%$ of Medicare Part D spending in 2009 and included the 6 protected classes and 6 classes with practically no generic competition. All variables were constructed to measure each drug relative to its class at a specific plan sponsor.

Results: We estimated that the shift toward generic utilization had cut in half the rate of increase in the price of a prescription during 2007-2009. Specifically, the results showed that (1) rapid generic penetration had significantly held down costs per prescription, (2) copayment and other benefit practices shifted utilization to generics and favored brands, and (3) price increases were generally greater in less competitive classes of drugs.
Conclusion: In many ways, Part $\mathrm{D}$ was implemented at a fortuitous time; since 2006, there have been relatively few new blockbuster drugs introduced, and many existing high-volume drugs used by beneficiaries were in therapeutic classes with multiplebrands and genericalternatives. Under these conditions, our paper showed that plan sponsors have been able to contain costs by encouraging use of generics or drugs offering greater value within therapeutic classes. It is less clear what will happen to future Part D costs if a number of new and effective drugs for beneficiaries enter the market with no real competitors.

Keywords: Medicare spending and utilization, Medicare Part D, generic dispensing rate, generic competition, out-of-pocket payment, cost-sharing elasticity, benefit management practices, prescription drug costs.

ISSN: 2159-0354

doi: http://dx.doi.org/10.5600/mmrr.004.01.a01 


\section{Medicare \& Medicaid Research Review} 2014: Volume 4, Number 1

\section{Mission Statement}

Medicare \& Medicaid Research Review is a peerreviewed, online journal reporting data and research that informs current and future directions of the Medicare, Medicaid, and Children's Health Insurance programs. The journal seeks to examine and evaluate health care coverage, quality and access to care for beneficiaries, and payment for health services.

\section{http://www.cms.gov/MMRR/}

\section{U.S. Department of Health \& Human Services Kathleen Sebelius Secretary}

\section{Centers for Medicare \& Medicaid Services \\ Marilyn Tavenner \\ Administrator}

Editor-in-Chief

David M. Bott, Ph.D.

The complete list of Editorial Staff and

Editorial Board members

may be found on the MMRR Web site (click link): $\underline{\text { MMRR Editorial Staff Page }}$

Contact: $\underline{\text { mmrr-editors@cms.hhs.gov }}$

Published by the

Centers for Medicare \& Medicaid Services.

All material in the Medicare \& Medicaid Research

Review is in the public domain and may be duplicated without permission. Citation to source is requested.

\section{Introduction}

The Medicare Part D benefit was established by the Medicare Modernization Act of 2003 (MMA) and, generally, has been looked upon as a success since its implementation in 2006. ${ }^{1}$ The majority of beneficiaries now have drug coverage, plan choices remain plentiful, and premium growth has been moderate (Kaiser Family Foundation, 2012). Most plans also score well in CMS's quality ratings. Indeed, some see Part D as a model for transforming all of Medicare (Moffit, 2011).

Nonetheless, as the average price of pharmaceutical drugs in the United States is higher than most other industrialized countries, there has been continuing policy interest in whether a greater government role in drug pricing under Part D may be considered. ${ }^{2}$ At a minimum, it would seem reasonable to examine the potential for long run cost control in this program. In many ways, Part D was implemented at a fortuitous time for its private plans to restrain cost growth. There have been relatively few new blockbuster drugs in recent years, and many existing high volume drugs used by beneficiaries were in therapeutic classes with

\footnotetext{
${ }^{1}$ The Medicare Modernization Act of 2003 established the Medicare Part D drug benefit following contentious debate. Issues concerning program costs and benefit design were significant, including whether the benefit should be provided through the traditional Medicare program or through private plan sponsors. Of particular interest was whether the government would be given authority for negotiating drug prices or whether it would be left entirely to plan sponsors and pharmaceutical benefit managers (PBMs). Reflecting the preferences of the majority party in the Congress at that time, the private market approach was chosen and government involvement in price negotiations were prohibited. ${ }^{2}$ Several lawmakers, at a committee hearing on July 21, 2011 titled "Reducing Medicare Drug Costs" by the Senate Special Committee on Aging, suggested legislation is needed to give the federal government more authority to control drug prices in Medicare. An earlier study found that, other than Japan, other countries' prices ranged from 6 percent to 33 percent lower than U.S. prices (Danzon \& Furukawa, 2003). Prices and availability of pharmaceuticals: evidence from nine countries. Health Affairs [Web Exclusive], Available at: http://content.healthaffairs.org/cgi/ content/full/hlthaff.w3.521v1/DC1
} 
multiple brand and generic alternatives. It is not clear what would happen to Part D expenditures in coming years if a number of new and effective drugs for beneficiaries enter the market with no real competitors.

A private plan sponsor model was chosen for Part D within the context of a continuing debate over whether value can best be improved by more government authority for pricing intervention, or whether it is best left to the interactions of private entities. In this paper, we argue that the ability of either private plans, pharmacy benefit managers (PBMs), or a government purchaser to restrain costs depends on the availability of competitive drugs within therapeutic classes, which translates to the ability of purchasers to obtain greater value for beneficiaries. That is, to what extent are there therapeutic alternatives to particular drugs, and what levers exist for purchasers to leverage these alternatives into lower treatment costs and greater value? How does competitiveness differ across classes of drugs used by beneficiaries? In this paper we analyze Part D data from 2007 to 2009 to assess drug shifting within classes, benefit policies affecting these shifts, and the impact they have on changes in average price per prescription across classes.

\section{Competition and Part D Structure}

There has always been a question about whether pharmaceutical markets are sufficiently competitive for market forces to operate in a manner that produces value in drug production and consumption; that is, whether market forces can be expected to result in a price that reasonably reflects societal benefits of the drug, marginal production costs, and an adequate rate of return to manufacturers for research and development costs. On one hand, the market power provided to manufacturers through patent protection and impact of third party coverage on consumer choice, lead many to believe these markets are necessarily noncompetitive. On the other hand, there are arguments that these markets are sufficiently competitive for two reasons: the availability of therapeutically equivalent brand drugs and, eventually, generics does result in competition among suppliers; and the ability of health plans and PBMs to negotiate price and shift volume among therapeutic alternatives effectively replaces the traditional consumer driven demand curve. The structure of Part D was based on the latter set of arguments for assuring cost control and value for beneficiaries and taxpayers.

Part D was implemented in January 2006 as a voluntary drug benefit for Medicare beneficiaries. The benefit is provided through a choice of private plans with Medicare subsidizing 74.5\% of the national average premium and providing additional assistance for premiums and out of pocket costs to low income (LIS) beneficiaries. In 2009, there were approximately 4,000 plans offered, including 1,689 standalone prescription drug plans (PDPs) and 2,039 offered by Medicare Advantage plans (MA-PDs). Approximately 26 million beneficiaries were enrolled in these plans. ${ }^{3}$ Total Medicare Part D spending was $\$ 53$ billion or about $10.7 \%$ of Medicare outlays in 2009.

The plan competition structure of Part D is based in part on tying the premium subsidy to the national average of plan bids. Plans with above average costs must then charge additional premiums while those below the average can reduce the beneficiary premium. Thus, plans compete based both on their premiums and on the quality of their benefit package. Within some limitations based on actuarial value and formulary

\footnotetext{
${ }^{3}$ In 2009, about 59\% (26 million) of the 45 million elderly and disabled beneficiaries enrolled in part D (31\% had other sources of creditable coverage and $10 \%$ had no drug coverage).
} 
guidance, plans have considerable latitude for varying deductible and copayment structure of the benefit, as well as other drugs to be included in the benefit package.

Plans can negotiate prices with manufacturers and implement several benefit management practices to control costs. They can use tiered copayments to provide beneficiaries with financial incentives for choosing higher value alternatives within therapeutic classes-either a generic equivalent to branded drugs or to competing brands that are favored due to the plan negotiating a better price, usually through rebate arrangements. Other benefit management practices, such as step therapy, quantity limitations, and prior approval can also be used to encourage higher value utilization.

Therapeutic classes with a number of alternatives of equivalent effectiveness, and for which the potential for within class shifting is substantial, might be labeled as more competitive. When plan sponsors can adjust copayments and other practices to shift a significant number of prescriptions among therapeutic alternatives, they have the ability to reduce the average cost per prescription directly. At the same time, they gain greater leverage in price negotiations with manufacturers. Where generic alternatives are not available, or particular drugs are unique in terms of their effectiveness, it is less clear whether market forces can assure value. In these cases, manufacturers have considerable latitude in setting prices and plans/PBMs have little leverage for negotiating price or shifting utilization. Indeed, based on potential differences in competitiveness across drug markets, it has been suggested that a more nuanced or selective approach be taken to any policy of government pricing intervention (Frank \& Newhouse, 2008). In the remainder of this paper, we examine differences in competitiveness among multiple therapeutic classes.

\section{Data and Methods}

The study examined changes in price and use from 2007 to 2009 of all drugs in 28 therapeutic classes. The classes accounted for $80 \%$ of Medicare part D spending in 2009 and included the 6 protected classes and 6 classes with practically no generic competition.

Principal research questions included: How does generic utilization differ among drug classes over time? Does change in price per prescription differ by competitiveness of each class? And, what benefit management practices are effective at shifting utilization to more favored alternatives within class?

The main source of data for the study was Part D's Prescription Drug Event file, which contains all claims for covered drugs. Additional information was obtained from the Health Plan Management System (HPMS) and First Data Bank. The units of analysis for thestudy were drug-plan combinations. The relevant information on pharmacy prices, quantity, and copayments were aggregated from the individual claims to reflect a specific drug at drug name level at each plan sponsor. For example, an observation might be Lipitor (all dosage levels) at Plan A. All observations were adjusted to reflect 30 day equivalent prescriptions.

For analyzing the relationships between prices, quantities, and copayments, all variables were constructed to measure each drug relative to its class at a specific plan sponsor. For example, quantity variables are measured as the number of 30 day equivalent prescriptions for a specific drug at a plan sponsor relative to the total number of 30 day prescriptions for all other drugs within the therapeutic class at that plan. Copayment and price per prescription are measured similarly, with denominators being the average for other drugs in the class. Prices reflect the total paid by both the plan and beneficiary at the pharmacy, but do not 
include any rebates negotiated by the plan. Generic dispensing rates are calculated for each therapeutic class at the plan level in each year.

We also calculated two price indices for each class of drugs. The first was a Laspeyres or fixed quantity weight index and the second reflected each year's quantity weights. The first index measures average price change per drug over the 2007-2009 period, while the second measures average price change per prescription allowing for shifts among drugs within the class.

\section{Results}

\section{Generic Dispensing Rate (GDR)}

GDRs for each class, as well as the total of the 28 classes, are displayed on Exhibit 1. Of these classes, 22 contained generic equivalents. Overall, nearly three quarters of 30 day equivalent prescriptions were for generic drugs in 2009. These drugs accounted for $25 \%$ of dollars, however, since their prices are significantly lower. It would be expected that GDRs for LIS enrollees would be lower than

Exhibit 1. Generic Dispensing Rate in 2009

\begin{tabular}{|c|c|c|c|c|c|c|}
\hline \multirow[b]{3}{*}{ Drug Classes } & & \multicolumn{5}{|c|}{ Generic Dispensing Rate ${ }^{1}$} \\
\hline & & \multicolumn{3}{|c|}{ All plans } & \multirow{2}{*}{$\begin{array}{c}\text { PDP } \\
\text { All } \\
\text { Enroll }\end{array}$} & \multirow{2}{*}{$\begin{array}{c}\text { MAPD } \\
\text { All } \\
\text { Enroll }\end{array}$} \\
\hline & & $\begin{array}{c}\text { All } \\
\text { Enroll }\end{array}$ & LIS & Non-LIS & & \\
\hline All & & 0.74 & 0.72 & 0.77 & 0.72 & 0.76 \\
\hline $\begin{array}{l}\text { ANGIOTENSIN II RECEPTOR } \\
\text { ANTAGONISTS }\end{array}$ & Blood Pressure medication & 0.00 & - & - & - & 0.00 \\
\hline $\begin{array}{l}\text { ANGIOTENSIN-CONVERTING } \\
\text { ENZYME INHIBITORS }\end{array}$ & Ace (blood pressure) & 0.99 & 0.99 & 0.99 & 0.99 & 0.99 \\
\hline ANTICONVUlSANTS & $\begin{array}{l}\text { Seizure Medications or CNS } \\
\text { drugs }\end{array}$ & 0.88 & 0.85 & 0.90 & 0.87 & 0.88 \\
\hline ANTIDEPRESSANTS & Mental Health or CNS drugs & 0.79 & 0.76 & 0.81 & 0.77 & 0.81 \\
\hline $\begin{array}{l}\text { ANTIMUSCARINICS/ } \\
\text { ANTISPASMODICS }\end{array}$ & Anti-Parkinson drugs & 0.34 & 0.34 & 0.35 & 0.35 & 0.33 \\
\hline ANTINEOPLASTIC AGENTS & Cancer medication & 0.67 & 0.66 & 0.67 & 0.67 & 0.66 \\
\hline Antipsychotic Agents & Mental Health or CNS drugs & 0.43 & 0.38 & 0.51 & 0.41 & 0.46 \\
\hline ANTIRETrovirals & HIV-drugs & 0.05 & 0.05 & 0.06 & 0.04 & 0.06 \\
\hline $\begin{array}{l}\text { BETA-ADRENERGIC } \\
\text { BLOCKING AGENTS }\end{array}$ & $\begin{array}{l}\text { Angina/High blood pressure/ } \\
\text { and abnormal heart rhythms }\end{array}$ & 0.95 & 0.94 & 0.95 & 0.94 & 0.96 \\
\hline BIGUANIDES & Diabetes medication & 0.97 & 0.97 & 0.97 & 0.97 & 0.97 \\
\hline $\begin{array}{l}\text { CHOLESTEROL ABSORPTION } \\
\text { INHIBITORS }\end{array}$ & Cholesterol lowering agents & - & - & - & - & - \\
\hline COUMARIN DERIVATIVES & Anticoagulation agents & 0.93 & 0.94 & 0.92 & 0.92 & 0.94 \\
\hline $\begin{array}{l}\text { CyClOOXYGENASE- } 2 \\
(\text { COX-2) INHIBITORS }\end{array}$ & $\begin{array}{l}\text { Non-steroidal anti- } \\
\text { inflammatory drug }\end{array}$ & - & - & - & - & - \\
\hline DIHYDROPYRIDINES & Calcium Channel Blockers & 0.94 & 0.93 & 0.94 & 0.94 & 0.94 \\
\hline $\begin{array}{l}\text { GENITOURINARY SMOOTH } \\
\text { MUSCLE RELAXANTS }\end{array}$ & Anticholinergic Agents & 0.40 & 0.38 & 0.41 & 0.38 & 0.43 \\
\hline
\end{tabular}




\begin{tabular}{|c|c|c|c|c|c|c|}
\hline \multirow[b]{3}{*}{ Drug Classes } & & \multicolumn{5}{|c|}{ Generic Dispensing Rate ${ }^{1}$} \\
\hline & & \multicolumn{3}{|c|}{ All plans } & \multirow{2}{*}{$\begin{array}{c}\text { PDP } \\
\text { All } \\
\text { Enroll }\end{array}$} & \multirow{2}{*}{$\begin{array}{c}\text { MAPD } \\
\text { All } \\
\text { Enroll }\end{array}$} \\
\hline & & $\begin{array}{c}\text { All } \\
\text { Enroll }\end{array}$ & LIS & Non-LIS & & \\
\hline LEUKOTRIENE MODIFIERS & $\begin{array}{l}\text { Agents to treat inflammation in } \\
\text { asthma and bronchitis }\end{array}$ & - & - & - & - & - \\
\hline LOOP DIURETICS & $\begin{array}{l}\text { High blood pressure, edema, } \\
\text { and Congestive heart failure }\end{array}$ & 1.00 & 1.00 & 0.99 & 0.99 & 1.00 \\
\hline OPIATE AGONISTS & Pain Killer & 0.95 & 0.93 & 0.96 & 0.94 & 0.96 \\
\hline $\begin{array}{l}\text { PARASYMPATHOMIMETIC } \\
\text { (CHOLINERGIC AGENTS) }\end{array}$ & Mild to Moderate Dementia & 0.12 & 0.11 & 0.14 & 0.12 & 0.13 \\
\hline $\begin{array}{l}\text { Platelet-AgGREgation } \\
\text { INHIBITORS }\end{array}$ & Antiplatelet drug & 0.12 & 0.13 & 0.11 & 0.08 & 0.14 \\
\hline PROTON-PUMP INHIBITORS & Ulcer \& Reflux & 0.69 & 0.62 & 0.72 & 0.66 & 0.72 \\
\hline $\begin{array}{l}\text { SELECTIVE ALPHA-1- } \\
\text { ADRENERGIC BLOCK.AGENT }\end{array}$ & $\begin{array}{l}\text { Benign prostate hyperplasia } \\
\text { agents }\end{array}$ & 0.06 & 0.11 & 0.04 & 0.05 & 0.06 \\
\hline THIAZIDE DIURETICS & $\begin{array}{l}\text { Blood pressure medication/ } \\
\text { edema agents }\end{array}$ & 0.99 & 0.99 & 0.99 & 0.99 & 0.99 \\
\hline THIAZOLIDINEDIONES & $\begin{array}{l}\text { Diabetes medication } \\
\text { (Type II) }\end{array}$ & - & - & - & - & - \\
\hline THYROID AGENTS & Agents for Thyroid disorders & 0.84 & 0.88 & 0.81 & 0.82 & 0.85 \\
\hline
\end{tabular}

those non-LIS enrollees since the former have their copayment subsidized and would tend to be less price sensitive. Likewise, it would be expected that GDRs for MA-PDs would exceed those for PDPs, because they have closer working relationships with their physician networks. The results are consistent with these expectations, but the differences are relatively small. Larger differences do exist between LIS and non LIS enrollees for antipsychotic agents, proton pump inhibitors and, to a lesser extent, statins.

As displayed on Exhibit 2, which compares GDRs for non-LIS beneficiaries in all three years, Part D plans appear to be successful at moving towards and maintaining high rates of generic utilization. In general, the GDRs for classes of drugs with relatively high generic utilization in
2007 either continued to increase or remained stable. Four classes in particular demonstrated rapid growth in the GDR over this period: parasympathomimetic (cholinergic agents), proton pump inhibitors, antipsychotics, and statins. These classes had generic versions of top selling drugs enter the market in recent years: galantamine hbr (Razadyne) in 2008, pantoprazole (Protonix) in 2007, Risperidone (Risperdal) in 2008, and simvastatin (Zocor) in 2006, respectively. Thus, beneficiaries in Part $\mathrm{D}$ plans shifted from brand to generic use rapidly.

\footnotetext{
${ }^{4}$ Moreover, since the last three classes are the same three classes for which the largest 2009 differences in GDR exist between LIS and non LIS enrollees, a reasonable hypothesis is that subsidized copayments result in slower movement from brands to generics, but eventually these rates become more equivalent.
} 
Exhibit 2. Generic Dispensing Rate for non-LIS in 2007-2009

\begin{tabular}{|c|c|c|c|c|c|}
\hline \multirow{2}{*}{ Drug Classes } & & \multicolumn{4}{|c|}{ Generic Dispensing Rate ${ }^{1}$} \\
\hline & & 2007 & 2008 & 2009 & $2007-2009^{2}$ \\
\hline All & & 0.70 & 0.75 & 0.77 & $10.1 \%$ \\
\hline \multicolumn{6}{|l|}{ Mostly Brand } \\
\hline $\begin{array}{l}\text { ANGIOTENSIN II RECEPTOR } \\
\text { ANTAGONISTS }\end{array}$ & Blood Pressure medication & - & - & - & - \\
\hline $\begin{array}{l}\text { CHOLESTEROL ABSORPTION } \\
\text { INHIBITORS }\end{array}$ & Cholesterol lowering agents & - & - & - & - \\
\hline $\begin{array}{l}\text { CYCLOOXYGENASE-2 (COX-2) } \\
\text { INHIBITORS }\end{array}$ & $\begin{array}{l}\text { Non-steriodal anti- } \\
\text { inflammatory drug }\end{array}$ & - & - & - & - \\
\hline INSULINS & Agents used to treat diabetes & - & - & - & - \\
\hline LEUKOTRIENE MODIFIERS & $\begin{array}{l}\text { Agents to treat inflammation } \\
\text { in asthma and bronchitis }\end{array}$ & - & - & - & - \\
\hline THIAZOLIDINEDIONES & Diabetes medication (Type II) & - & - & - & - \\
\hline \multicolumn{6}{|c|}{ Emerging Competitive-generic competition } \\
\hline $\begin{array}{l}\text { ANGIOTENSIN-CONVERTING } \\
\text { ENZYME INHIBITORS }\end{array}$ & \multicolumn{4}{|c|}{ ENZYME INHIBITORS } & $9.1 \%$ \\
\hline $\begin{array}{l}\text { BETA-ADRENERGIC BLOCKING } \\
\text { AGENTS }\end{array}$ & $\begin{array}{l}\text { Angina/High blood pressure/ } \\
\text { and abnormal heart rhythms }\end{array}$ & 0.80 & 0.97 & 0.95 & $18.7 \%$ \\
\hline DIHYDROPYRIDINES & Calcium Channel Blockers & 0.73 & 0.93 & 0.94 & $29.2 \%$ \\
\hline HMG-COA REDUCTASE & Statins & 0.58 & 0.67 & 0.71 & $22.2 \%$ \\
\hline \multicolumn{6}{|l|}{ INHIBITORS } \\
\hline PROTON-PUMP INHIBITORS & Ulcer \& Reflux & 0.43 & 0.64 & 0.72 & $67.9 \%$ \\
\hline THYROID AGENTS & Agents for Thyroid disorders & 0.77 & 0.80 & 0.81 & $4.8 \%$ \\
\hline \multicolumn{6}{|l|}{ Competitive-generic saturation } \\
\hline BIGUANIDES & Diabetes medication & 0.98 & 0.97 & 0.97 & $-1.2 \%$ \\
\hline COUMARIN DERIVATIVES & Anticoagulation agents & 0.88 & 0.90 & 0.92 & $4.0 \%$ \\
\hline LOOP DIURETICS & $\begin{array}{l}\text { High blood pressure, edema, } \\
\text { and Congestive heart failure }\end{array}$ & 0.99 & 0.99 & 0.99 & $0.3 \%$ \\
\hline OPIATE AGONISTS & Pain Killer & 0.97 & 0.96 & 0.96 & $-1.0 \%$ \\
\hline THIAZIDE DIURETICS & $\begin{array}{l}\text { Blood pressure medication/ } \\
\text { edema agents }\end{array}$ & 1.00 & 1.00 & 0.99 & $-0.2 \%$ \\
\hline \multicolumn{6}{|l|}{ Protected } \\
\hline ANTICONVULSANTS & $\begin{array}{l}\text { Seizure Medications or CNS } \\
\text { drugs }\end{array}$ & 0.81 & 0.82 & 0.90 & $11.2 \%$ \\
\hline ANTIDEPRESSANTS & Mental Health or CNS drugs & 0.77 & 0.79 & 0.81 & $4.8 \%$ \\
\hline ANTIPSYCHOTIC AGENTS & Mental Health or CNS drugs & 0.32 & 0.41 & 0.51 & $57.0 \%$ \\
\hline ANTIRETROVIRALS & HIV-drugs & 0.06 & 0.06 & 0.06 & $-9.4 \%$ \\
\hline IMMUNOSUPPRESSIVE AGENTS & Immunosuppressive agents & 0.35 & 0.34 & 0.37 & $6.9 \%$ \\
\hline ANTINEOPLASTIC AGENTS & Cancer medication & 0.62 & 0.64 & 0.67 & $8.0 \%$ \\
\hline LESS COMPETITIVE-LOW & & - & - & - & - \\
\hline GENERIC DISPENSING RATE & & & & & \\
\hline
\end{tabular}


Exhibit 2 Continued. Generic Dispensing Rate for non-LIS in 2007-2009

\begin{tabular}{|c|c|c|c|c|c|}
\hline \multirow[b]{2}{*}{ Drug Classes } & & \multicolumn{4}{|c|}{ Generic Dispensing Rate ${ }^{1}$} \\
\hline & & 2007 & 2008 & 2009 & $2007-2009^{2}$ \\
\hline $\begin{array}{l}\text { PARASYMPATHOMIMETIC } \\
\text { (CHOLINERGIC AGENTS) }\end{array}$ & Mild to Moderate Dementia & 0.09 & 0.09 & 0.14 & $60.7 \%$ \\
\hline $\begin{array}{l}\text { PLATELET-AGGREGATION } \\
\text { INHIBITORS }\end{array}$ & Antiplatelet drug & 0.19 & 0.12 & 0.11 & $-39.5 \%$ \\
\hline $\begin{array}{l}\text { SELECTIVE ALPHA-1- } \\
\text { ADRENERGIC BLOCK.AGENT }\end{array}$ & $\begin{array}{l}\text { Benign prostate hyperplasia } \\
\text { agents }\end{array}$ & 0.05 & 0.04 & 0.04 & $-20.4 \%$ \\
\hline
\end{tabular}

\section{Changes in Prices}

Between 2007 and 2009, total payments made by Part D plans and beneficiaries to pharmacies for the 28 drug classes increased by approximately $21 \%$. The estimated increase in cost per enrollee for these classes was approximately $6 \%$, meaning that most of that change (about 14\%) was due to increased Part D enrollment. Of the $6 \%$ increase in per enrollee cost, $2 \%$ was due an increase in the number of prescriptions per enrollee and the remaining $4 \%$ to the average price per prescription.
In contrast to the $4 \%$ increase in average price per prescription (variable quantity weight index) between 2007 and 2009, prices of individual drugs (the fixed weight Laspeyres index) increased by more than $8 \%$. The difference in the two indices largely reflects the growth in generic utilization within the drug classes. In other words, the shift toward less expensive drugs, including generic competition, had cut in half the rate of increase in the price of a prescription. Exhibit 3 displays the two price indexes for the 28 drug classes.

Exhibit 3. Price Indices By Competitive Status, 2009-2007

\begin{tabular}{|c|c|c|c|}
\hline \multirow[b]{3}{*}{ Drug Classes } & & \multicolumn{2}{|c|}{ Change in Average Price Per Claim } \\
\hline & & Quantity Weight* & Actual $^{* *}$ \\
\hline & & fixed in 2007 & Q 09 for P 09 \\
\hline All & & 1.080 & 1.043 \\
\hline \multicolumn{4}{|l|}{ Mostly Brand } \\
\hline ANGIOTENSIN II RECEPTOR & Blood Pressure medication & 1.224 & 1.282 \\
\hline \multicolumn{4}{|l|}{ ANTAGONISTS } \\
\hline CHOLESTEROL ABSORPTION & Cholesterol lowering agents & 1.161 & 1.231 \\
\hline \multicolumn{4}{|l|}{ INHIBITORS } \\
\hline CYCLOOXYGENASE-2 (COX-2) & Non-steriodal anti-inflammatory & 1.162 & 1.219 \\
\hline INHIBITORS & drug & & \\
\hline INSULINS & Agents used to treat diabetes & 1.215 & 1.423 \\
\hline LEUKOTRIENE MODIFIERS & $\begin{array}{l}\text { Agents to treat inflammation in } \\
\text { asthma and bronchitis }\end{array}$ & 1.139 & 1.205 \\
\hline THIAZOLIDINEDIONES & Diabetes medication (Type II) & 1.153 & 1.283 \\
\hline
\end{tabular}




\begin{tabular}{|c|c|c|c|}
\hline \multirow[b]{3}{*}{ Drug Classes } & & \multicolumn{2}{|c|}{ Change in Average Price Per Claim } \\
\hline & & Quantity Weight* & Actual $^{* *}$ \\
\hline & & fixed in 2007 & Q 09 for P 09 \\
\hline \multicolumn{4}{|c|}{ Emerging Competitive-generic competition } \\
\hline ANGIOTENSIN-CONVERTING ENZYME & Ace (blood pressure) & 0.906 & 0.761 \\
\hline \multicolumn{4}{|l|}{ INHIBITORS } \\
\hline BETA-ADRENERGIC BLOCKING AGENTS & $\begin{array}{l}\text { Angina/High blood pressure/ } \\
\text { abnormal heart rhythms }\end{array}$ & 1.020 & 0.785 \\
\hline DIHYDROPYRIDINES & Calcium Channel Blockers & 0.907 & 0.641 \\
\hline HMG-COA REDUCTASE INHIBITORS & Statins & 1.047 & 0.857 \\
\hline PROTON-PUMP INHIBITORS & Ulcer \& Reflux & 1.091 & 0.916 \\
\hline THYROID AGENTS & Agents for Thyroid disorders & 0.994 & 0.994 \\
\hline \multicolumn{4}{|l|}{ Competitive-generic saturation } \\
\hline BIGUANIDES & Diabetes medication & 0.880 & 1.059 \\
\hline COUMARIN DERIVATIVES & Anticoagulation agents & 0.974 & 0.947 \\
\hline LOOP DIURETICS & $\begin{array}{l}\text { High blood pressure, edema, and } \\
\text { Congestive heart failure }\end{array}$ & 0.907 & 1.039 \\
\hline OPIATE AGONISTS & Pain Killer & 0.966 & 1.088 \\
\hline THIAZIDE DIURETICS & $\begin{array}{l}\text { Blood pressure medication/edema } \\
\text { agents }\end{array}$ & 0.946 & 1.067 \\
\hline \multicolumn{4}{|l|}{ Protected } \\
\hline ANTICONVULSANTS & Seizure Medications or CNS drugs & 1.138 & 0.850 \\
\hline ANTIDEPRESSANTS & Mental Health or CNS drugs & 1.001 & 1.003 \\
\hline ANTIPSYCHOTIC AGENTS & Mental Health or CNS drugs & 1.107 & 1.080 \\
\hline ANTIRETROVIRALS & HIV-drugs & 0.958 & 1.205 \\
\hline IMMUNOSUPPRESSIVE AGENTS & Immunosuppressive agents & 1.070 & 1.099 \\
\hline ANTINEOPLASTIC AGENTS & Cancer medication & 1.126 & 1.161 \\
\hline \multicolumn{4}{|c|}{ Less Competitive-low generic dispensing rate } \\
\hline ANTIMUSCARINICS/ANTISPASMODICS & Anti-parkinson drugs & 1.006 & 1.400 \\
\hline $\begin{array}{l}\text { GENITOURINARY SMOOTH MUSCLE } \\
\text { RELAXANTS }\end{array}$ & Anticholinergic Agents & 1.152 & 1.195 \\
\hline $\begin{array}{l}\text { PARASYMPATHOMIMETIC } \\
\text { (CHOLINERGIC AGENTS) }\end{array}$ & Mild to Moderate Dementia & 1.138 & 1.221 \\
\hline PLATELET-AGGREGATION & Antiplatelet drug & 1.097 & 1.246 \\
\hline INHIBITORS & & & \\
\hline SELECTIVE ALPHA-1-ADRENERGIC & Benign prostate hyperplasia agents & 1.449 & 1.517 \\
\hline BLOCK.AGENT & & & \\
\hline
\end{tabular}

To examine in detail the impact of competition of generics and alternative drugs on prices, we grouped the 28 classes into five categories based on the availability of generics and the 2007-2009 
change in GDRs: (1) mostly brand (several branded drugs but no generics); (2) emerging competitive (generics recently available and GDRs increasing); (3) competitive (generic saturated, little room for change in GDR); (4) Part D's protected classes; and (5) less competitive (generics available, but relatively low GDRs).

For the mostly brand and less competitive groups, average prices of individual drugs (fixed weight index) increased more rapidly between 2007 and 2009 than for either of the emerging competitive and competitive groups (Exhibit 3 ). For the latter two groups, prices either declined on average or grew moderately. Even more striking differences can be found for average price per prescription (variable weight index). For the mostly brand and less competitive groups, increases in average price per prescription exceeded increases in individual drug prices, indicating shifts to more expensive drugs within class. For the emerging competitive group, the shift towards generics caused the change in average price per prescription to be significantly lower than average price change; in fact, the average price per prescription fell significantly for all classes in this group. In drug classes that already experienced high rates of generic utilization, average drug prices declined, but the price per prescription increased indicating a shift within classes to higher price generics.

It should be noted that factors underlying the price effects for these groupings can differ by class. Clinical practice patterns and patient specific factors can affect the degree of within class substitution among drugs. For example, while shifting to simvastatin seems to have been at the expense of several brand statins, use of Respiredone seems to have been a substitute only for the specific brand drug Respirdal. Some classes contain drugs for multiple indications, potentially limiting substitution opportunities. For example, while there were generic versions of other drugs available within the selective alpha-1 adrenergic block agent class, Flomax was essentially a unique drug for treatment of benign prostatic hyperplasia until late in 2009 when a generic equivalent (Tamsulosin) became available. Flomax's rapid increase in price and utilization during this period dominated the results for this class.

The results for the six protected classes demonstrate elements of both the competitive and noncompetitive classes. Markets for protected classes may be less competitive regardless of the number of brands and generics available, because Part D plans are given less flexibility for which drugs to include on the formulary. In addition, prior authorization and step therapy approaches are not allowed. While plans do not have these tools available, copayment tiers remain an option for them to shift utilization to favored drugs. Thus, the patterns for both price indexes are less consistent than in the other groups-based on the within class availability of generics and the degree to which clinical practice allows for therapeutic substitution.

\section{The Impact of Copayments and Other Benefit Management Strategies on Utilization within Classes}

We used fixed effects regression models on combined 2007-2009 data to examine the impact of copayments and other benefit management strategies on utilization within classes. The primary dependent variable was the annual quantity (number of 30 day equivalent prescriptions) of a specific drug at each Part D plan, relative to the quantity of all other drugs within the same class at that plan. The key independent variable was the plan level copayment for that drug relative to the average 
copayment for all other drugs within the class. In the first set of models, plan level and year effects were fixed so that estimates captured variation across plan-drug combinations. The second set of models captured the impact of changes in copayments from 2007 to 2009 on relative quantity within plan-drug combinations. These plan-drug fixed effects models also examined the impact of imposing step therapies, quantity limitations, or prior authorization requirements for a specific drug between 2007 and 2009. Estimates from the first set of models may be interpreted as the long run effect of out of pocket payment on within class quantities, the second set as estimates of short run (two year) impact.

We also investigated whether there were differences in the copayment effect between generic and brand drugs. One hypothesis is that once generics become available, manufacturers of the brand drugs do not adjust price to compete with them, but instead strive to maintain some market share at the higher brand price. One corollary to this hypothesis is that the resulting smaller market place for the brands would exhibit a much lower price or copayment effect, because the remaining consumers would have a strong brand preference. On the other hand, if the market is more health plan/PBM than consumer driven, there still may be aggressive competition for shares of the brand market.

Exhibit 4 summarizes basic regression results. The impact of relative copayments on relative quantity across all plan-drug combinations is -0.39 . That is, a $10 \%$ increase in copayment for a specific drug relative to copayments for other drugs in the class would reduce utilization by about $4 \%$ relative to the other drugs in the class. It is important to note that this effect does not

\section{Exhibit 4. Impact of Out-of-Pocket Costs on Utilization of Medicare Prescription Drugs}

Model 1: Fixed effects at the plan-level

Model 2: Change during 2007-2009 at the plan/drug-level

\begin{tabular}{|c|c|c|c|c|}
\hline \multirow[b]{4}{*}{ Left-hand Side Variable } & \multirow{2}{*}{\multicolumn{2}{|c|}{$\begin{array}{l}\text { Model } 1^{\mathrm{a}} \\
\text { Fixed effect at plan level }\end{array}$}} & \multicolumn{2}{|c|}{ Model $2^{b}$} \\
\hline & & & \multicolumn{2}{|c|}{ Change effect at plan-drug level } \\
\hline & All drugs & Brand/Generic & All drugs & Brand/Generic \\
\hline & \multicolumn{2}{|c|}{ Util. of Drug relative to its Class } & \multicolumn{2}{|c|}{$\begin{array}{l}\text { Ratio of Util. of Drug relative to its } \\
\text { Class in } 2009-2007\end{array}$} \\
\hline \multicolumn{5}{|l|}{ Right-hand Side Variable } \\
\hline OOP & $-0.39 *$ & - & $-0.08^{\star}$ & - \\
\hline OOP for Brand: & - & $-0.54^{*}$ & - & $-0.24^{\star}$ \\
\hline for Generic: & - & $-0.27^{\star}$ & - & $-0.01^{\star}$ \\
\hline Changes at the & Prior authorization & - & $-0.126^{*}$ & $-0.13^{\star}$ \\
\hline plan-drug level & Step therapy & - & $-0.233^{\star}$ & $-0.22^{\star}$ \\
\hline over 2007-2009 for: & Quantity limitation & - & $-0.059^{*}$ & $-0.05^{\star}$ \\
\hline R-square & 0.27 & 0.28 & 0.01 & 0.02 \\
\hline $\mathrm{N}$ & $2,366,783$ & $2,366,783$ & 397,064 & 397,064 \\
\hline
\end{tabular}


suggest a reduction in overall utilization within a class of drugs, but a substitution within class. The impact among brand drugs $(-0.54)$ is twice as large as for generics $(-0.27)$, indicating more aggressive competition within the brand market once generic versions become available.

The second panel on Exhibit 4 displays the results for the fully fixed effects models (plandrug fixed effects). These results suggest that the short run copayment effect within plan-drug combinations is much smaller than the longer run impact. That is, over the two year period, a 10 percent increase in relative copayment would result in approximately 1 percent reduction in relative utilization;-1.5 percent when the analysis is restricted to the competitive classes (not shown on Exhibit 4). In addition, the within brand effect is much larger in magnitude than the within generic effect. Finally, application of prior authorization, step therapy, or quantity limitation policies at the plan-drug level between 2007 and 2009 all resulted in significant reductions in utilization for those drugs relative to others in the class.

\section{Conclusions and Policy Implications}

The results presented in this paper suggest Part D plans have been successful at encouraging the use of lower cost generic drugs as they become available within drug classes. These shifts are accomplished through various tools that include tiered copayment and benefit management practices.

The cost implications of generic competition are significant. The utilization shift toward less expensive drugs reduced the growth in average cost per prescription significantly relative to price increases of individual drugs. As an upper bound for potential savings, we estimated that total prescription drug spending in Medicare
Part D would have been $\$ 33$ billion lower (or $60 \%$ of total part D spending) in 2009 if there were $100 \%$ GDRs in classes for which generics were available.

Our analyses also showed that there are differences in competitiveness among markets for drugs. These differences are based on the availability of multiple drugs-especially generics-that are therapeutically equivalent substitutes within classes. These differences are also based on purchasers' ability to use a number of benefit management practices, including copayment tiers, to shift utilization to favored alternatives.

The results suggest that the availability of generics and the ability to encourage their use does result in differential "competitiveness" across classes. These differences directly affect growth in the price per drug and average cost per prescription. For the 2007-2009 period, average prices for drugs (the fixed weight index) in more competitive therapeutic classes grew more slowly than for drugs in the less competitive classes. More importantly, in classes for which generic use is growing rapidly, the average cost of a prescription can decline significantly.

These results provide some support for the position that a private plan model for Part D can and has constrained cost growth, but only when choices among drugs and appropriate benefit management tools are available. Conversely, the results also suggest that prices for unique drugs and classes without generic versions do seem to have increased more rapidly than those in competitive classes. Together, the results raise the importance of carefully monitoring Part D spending to the extent that the future brings potentially less competitive drugs associated with the diffusion of new and effective "blockbuster" drugs. 


\section{Disclaimer}

The authors have been requested to report any funding sources and other affiliations that may represent a conflict of interest. The authors reported that there are no conflict of interest sources. The views expressed in this article are those of the authors and do not represent official policy of the Department of Health and Human Services.

\section{Correspondence}

StevenSheingold,Ph.D.,DHHS/ASPE200Independence Avenue, SW, Washington, DC 20201, Steven.Sheingold@ hhs.gov, Tel. 202-690-7387, Fax. 202-260-2524.

\section{Acknowledgment}

The paper, "Impacts Of Generic Competition And Benefit Management Practices On Spending For Prescription Drugs: Evidence From Medicare's Part D Benefit" was prepared by Steven H. Sheingold and Nguyen Xuan Nguyen under the direction of Richard Kronick and Nancy Delew. Assistance in developing databases was provided by Acumen.

\section{References}

Danzon P., \& Furukawa, M. F. (2003, October). Prices and availability of pharmaceuticals: evidence from nine countries. Health Affairs [Web Exclusive]. Retrieved from: http://content.healthaffairs.org/ cgi/content/full/hlthaff.w3.521v1/DC1

Frank, R. G. \& Newhouse, J. (2008, January). Should Drug Prices Be Negotiated Under Part D of Medicare? And If So, How? Health Affairs, 27(1), 33-43. Retrieved from http:// content.healthaffairs.org/content/27/1/33. full.pdf + html? sid=f0dcf675-6a68-4471 8ddc-2577bc57c796 PubMed http://dx.doi. org/10.1377/hlthaff.27.1.33

Kaiser Family Foundation (2012, November). The Medicare Prescription Drug Benefit. Medicare Policy Factsheet. Retrieved from: http://www. kff.org/medicare/upload/7044-13.pdf

Moffit, R.E. (2011, November 28). The Second Stage of Medicare Reform: Moving To a PremiumSupport Program. The Heritage Foundation Backgrounder (No. 2626). Retrieved from: http://thf_media.s3.amazonaws.com/2011/pdf/ bg2626.pdf 